\title{
Sistem Informasi E-Menu Pada Café Raego Berbasis Web Mobile
}

\author{
Sukardi $^{* 1}$, Eric Alfonsius ${ }^{2}$, Ade Yuni Safitri ${ }^{3}$ \\ 1,2,3 Program Studi Sistem Informasi STMIK Adhi Guna \\ E-mail:
}

\begin{abstract}
Abstrak
E-menu merupakan aplikasi yang dapat mengelola pesanan pelanggan sehingga dapat memudahkan baik pemilik café dan pelanggan dalam melakukan aktivitas pemesanan menu. Tujuan dari Penelitian ini adalah membangun suatu sistem informasi e-menu berbasis web mobile yang dapat membantu dalam proses pelayanan dan penjualan pada Cafe Raego. Dalam penerapannya pembuatan website ini menggunakan metode progressive web application sehingga aplikasi web yang telah dikembangkan dapat terinstal ke perangkat smartphone pengguna atau konsumen. Metode pengembangan sistem dalam Penelitian ini menggunakan metode waterfall, alat bantu pengembangan sistem menggunakan Unified Modeling Language, teknik pengujian sistem menggunakan metode pengujian Skala Likert untuk mengukur tingkat kelayakan program yang telah dikembangkan. Dengan menggunakan metode uji Skala Likert menunjukkan hasil 80.5\% dengan kategori "Sangat Layak". Kesimpulan yang didapat adalah sistem yang dihasilkan dapat berjalan sesuai dengan yang diharapkan oleh Penulis.
\end{abstract}

Kata Kunci-E-menu, web-mobile, skala likert, cafe

\begin{abstract}
E-menu is an application that can manage customer orders so that it can facilitate both café owners and customers in making menu ordering activities. The purpose of this research is to build a mobile web-based e-menu information system that can assist in the service and sales process at Raego Cafe. In application, making this website uses a progressive web application method so that web applications that have been developed can be installed to the user's smartphone or consumer device. The system development method in this research uses the waterfall method, the system development tool uses the Unified Modeling Language, the system testing technique uses the Likert Scale testing method to measure the feasibility of the program that has been developed. Using the Likert Scale test method showed 80,5\% results with the category "Very Good". The conclusion obtained is that the resulting system can run as expected by researchers.
\end{abstract}

Keywords - E-menu, web-mobile, skala likert, cafe

\section{Pendahuluan}

Kebutuhan akan sistem informasi bagi semua jenis organisasi menyebabkan perkembangan sistem informasi yang begitu pesat. Dengan adanya sistem informasi dalam suatu instansi atau perusahaan diharapkan dapat meningkatkan kinerja dari organisasi tersebut, karena informasi yang disajikan dalam bentuk digital sehingga pengolahan dan penyajiannya dapat dilakukan dengan cepat, tepat dan akurat [1]. Semua dampak dari perkembangan sistem informasi dapat dilihat dengan banyaknya penggunaan media informasi pada instansi atau perusahaan, bahkan gaya hidup yang dapat dikatakan telah menjadi kebutuhan pokok telah banyak menggunakan media informasi sebagai alat pemenuh kebutuhan. Salah satu jenis usaha yang seharusnya tidak lepas dari pemanfaatan media informasi adalah cafe. 
Keberhasilan suatu cafe tercermin dari kemampuan cafe tersebut dalam memanfaatkan teknologi informasi dan juga memberikan pelayanan terhadap kepuasan pelanggan yang ada. Kepuasan pelanggan dapat diketahui dari pelayanan dan fasilitas yang dirasakan terhadap cafe tersebut seperti makanan dan minuman, fasilitas-fasilitas yang ada dan pelayanan yang diterima [2]. Sehingga pelanggan menjadi betah dan datang kembali berulang-ulang. Hal inipun berlaku pada Cafe Raego dalam meningkatkan pelayanan, Cafe Raego mengutamakan beberapa upaya seperti dengan ramah menyambut pelanggan, memudahkan pelanggan dalam memesan suatu menu dengan cara mencatat pesanan dari pelanggan, menyebutkan ulang pesanan yang telah dipesan dan menyajikan makanan yang telah siap saji. Selain itu, Cafe Raego melakukan promosi di berbagai media sosial sepeti facebook, instagram, dan twitter.

Dari observasi awal yang dilakukan, masih terdapat beberapa kendala seperti dalam proses pemesanan menu masih berupa catatan di atas kertas sehingga rentan akan kesalahan dalam pencatatan. Selain itu, untuk pemesanan pesan antar, Cafe Raego hanya mengandalkan media sosial untuk melakukan promosi. Belum adanya sistem pencatatan pemesanan menu yang terkomputerisasi menyebabkan pemilik usaha mengalami kesulitan dalam memonitoring dan juga memanajemen proses bisnisnya. Selain itu pelanggan juga sangat terbatas dalam mendapatkan informasi mengenai produk-produk yang ada pada Cafe Raego. Melihat dari masalah yang ada, maka dirasa perlu mengembangkan suatu sistem informasi yang dapat mengatasi tersebut, sehingga kualitas pelayanan dari Cafe Raego menjadi lebih baik. Salah satu solusi yang dapat digunakan adalah dengan membangun suatu sistem informasi $e$-menu berbasis web mobile yang dapat diakses di mana saja oleh pelanggan. Sistem informasi tersebut dapat memudahkan pelanggan dalam melakukan pemesanan menu yang diinginkan karena bisa langsung melalui perangkat smartphone sendiri dan memudahkan pelayan melihat secara detail menu-menu pesanan dari setiap pelanggan atau konsumen. Maka dari solusi tersebut, Penulis bermaksud untuk melakukan Penelitian dengan judul "Sistem Informasi E-Menu Pada Cafe Raego Berbasis Web Mobile".

\section{Metode Penelitian}

Metode Penelitian yang digunakan dalam Penelitian ini merujuk pada proses pengembangan sistem yang ada. Setelah melakukan observasi dan pengumpulan data, maka didapatkan hasil berikut ini:

\subsection{Prosedur Penelitian}

Pada Gambar 1 menunjukkan proses tahapan pengembangan sistem informasi e-menu yang dimulai dari Identifikasi Masalah, Studi Literatur topik terkait Penelitian serta Analisa sistem dan data yang ditemukan pada waktu observasi sampai dengan perancangan dan uji coba (implementasi).

\subsubsection{Identifikasi Permasalahan}

Dari observasi awal yang dilakukan, masih terdapat beberapa kendala seperti dalam proses pemesanan menu masih berupa catatan di atas kertas sehingga rentan akan kesalahan dalam pencatatan pesanan pelanggan. 


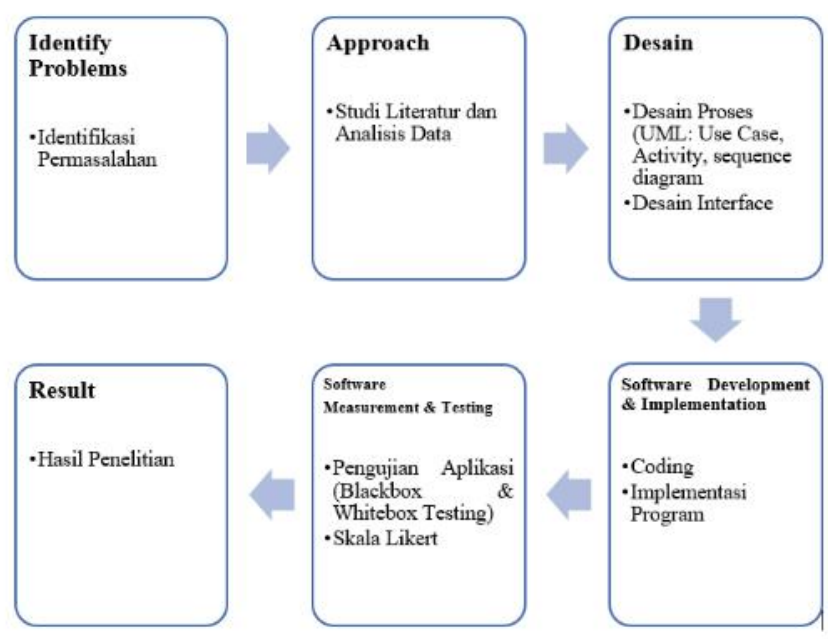

Gambar 1. Alur Penelitian

\subsubsection{Studi Literatur}

Studi literatur yang digunakan dalam Penelitian ini merujuk pada beberapa Penelitian yang berkaitan dari segi topik yang dibahas.

a. Perancangan Sistem

Perancangan [3] adalah tahapan awal dalam fase rekayasa perangkat lunak dan pembuatan prototipe alat. Perancangan pun dapat berupa proses penerapan berbagai macam metode dan Teknik serta analisa yang bertujuan untuk mendefinisikan serta membuat model yang terdiri dari satu proses atau satu sistem secara detail dalam tahapan realisasi sistem tersebut sehingga Fase ini dapat disebut core atau inti dari proses rekayasa perangkat lunak. Fase perancangan terdiri dari: Perancangan Database, Perancangan Arsitektur serta Perancangan interface/tampilan dari sistem yan akan dibangun tersebut. [4] Setelah fase perancangan akan menghasilkan tahapan selanjutnya membuat prototipe aplikasi yang akan dibuat melalui tahapan coding dan implementasi desain yang telah dibuat.

b. Definisi E-Menu

E-Menu (Electonic Menu) adalah penggunaan jaringan komputer untuk melakukan pemesanan makanan atau minuman pada sebuah rumah makan atau restoran yang dilakukan secara elektronik. Pengertian E-menu diatas diambil dari pengertian e-commerce (singkatan E) yaitu pembelian, penjualan dan pemasaran barang serta jasa melalui sistem elektronik.

c. Definisi Web-Mobile

Mobile web merupakan sebuah kumpulan halaman html dengan berbasis browser, yang dapat diakses dengan menggunakan perangkat portable seperti smartphone dan gadget/tablet melalui jaringan internet atau telekomunikasi berupa 3G, 4G, atau wifi. Karateristik yang jelas yang membedakan situs web mobile dari website standart adalah kenyataan bahwa web mobile dirancang untuk meng-handle layar dan layar sentuh yang lebih kecil. Seperti situs web apapun, web mobile dapat menampilkan sebuah text atau konten data gambar, audio dan vidio atau penggabungan dari beberapa konten yang berada pada layar sebuah smartphone dan tentu juga dipengaruhi oleh keterbatasan ukuran layar dan jenis layar sentuhnya.

Didalam mobile web mempunyai prinsip dalam sistemnya, yakni develope once run yang dapat berartikan bahwa mobile web ini beroperasi dalam lintas platform untuk sekali pengembangan. Jadi kesimpulannya mobile web lebih relatif tidak membutuhkan banyak biaya dalam proses pengembangan jika dibandingkan dengan mobile aplikasi disebabkan dapat berjalannya dengan baik disemua browser dan platform mobile. 


\subsubsection{Desain (Perancangan)}

Desain dalam Penelitian ini merujuk pada desain proses dan desain interface. Adapun secara lebih detail dijelaskan sebagai berikut:

a. Desain Proses

Desain proses yang ada dalam Penelitian ini didasari dari proses analisis sistem berjalan dan analisis sistem. Adapun desain proses yang ada dalam Penelitian ini terdiri dari beberapa proses yakni pembuatan use case diagram yang ditunjukkan pada gambar 2 .

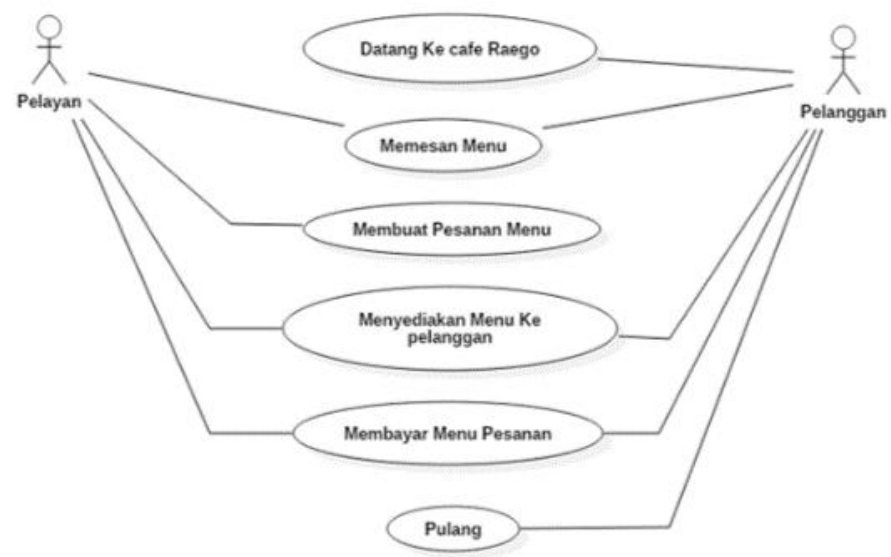

Gambar 2. Use Case Diagram

b. Desain Interface

Desain interface yang ada dalam Penelitian ini ditunjukkan pada gambar 3.
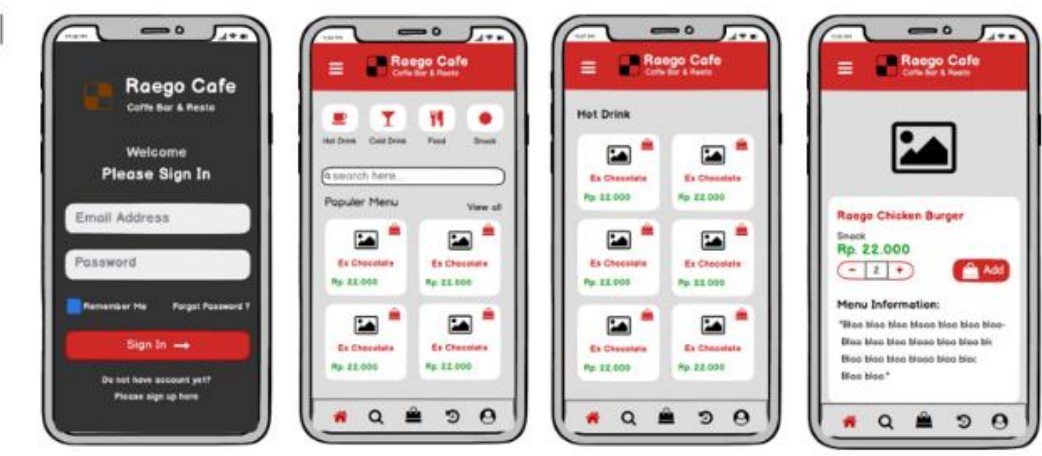

Gambar 3. Desain Tampilan Interface

\section{Hasil dan Pembahasan}

Hasil dan pembahasan yang ada dalam Penelitian ini merujuk pada hasil implementasi tampilan sistem informasi setelah dijalankan dan hasil pengujian sistem dengan menggunakan pengujian kualitatif yakni dengan meminta tanggapan kuesioner dari pengguna sistem ini sebagai berikut:

\subsection{Hasil Implementasi}

Implementasi merupakan tahap penerapan desain rancangan web yang ada sebelumnya. Dalam tahap ini Penulis melakukan pengkodean sistem berdasarkan dari use case dan desain 
rancangan web. Adapun hasil implementasi dari pengkodean sistem tersebut ditunjukkan pada gambar 4 dan 5 berikut ini.
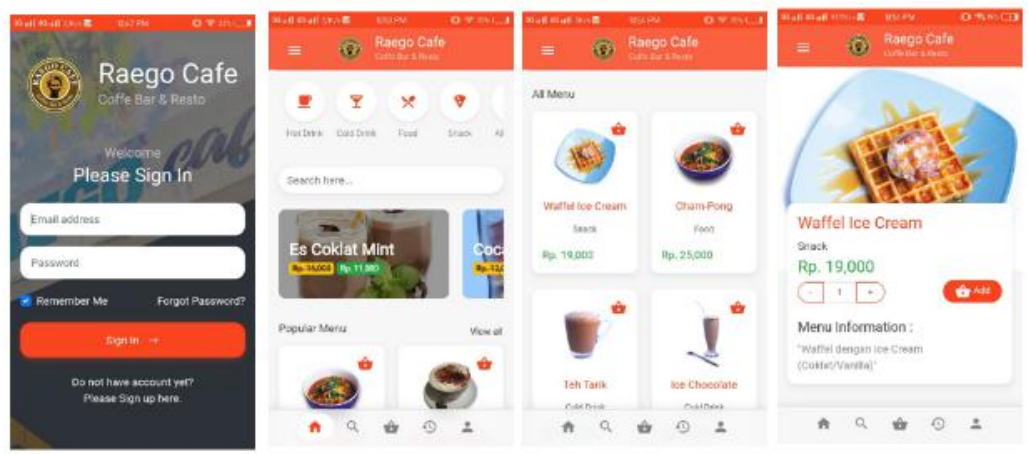

Gambar 4. Hasil Implementasi Sistem Informasi E-Menu (Tampilan Mobile)

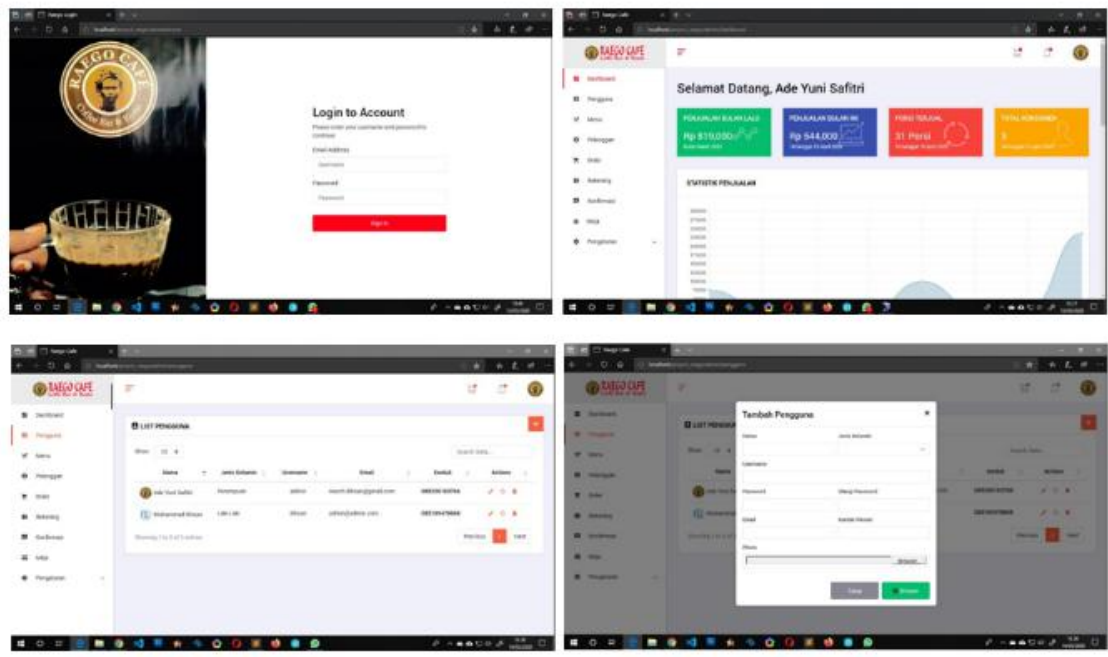

Gambar 5. Hasil Implementasi Sistem Informasi E-Menu (Tampilan Admin Panel)

\subsection{Hasil Pengujian}

Pada bagian ini Penulis akan memaparkan hasil pengujian terhadap pengembangan aplikasi e-menu pada Cafe Raego. Untuk mengetahui hasil dari pengujian aplikasi tersebut, Penulis dalam hal ini menggunakan metode pengujian Skala Likert. Hasil uji kelayakan aplikasi oleh pengguna aplikasi e-menu pada Cafe Raego (40 orang pelanggan pengguna aplikasi e-menu pada Cafe Raego). Berikut tabulasi tanggapan responden yang dapat dilihat pada tabel 1 berikut ini:

Tabel 1. Tabulasi Skor Tanggapan Responden

\begin{tabular}{|l|l|l|l|l|l|}
\hline \multirow{2}{*}{ Variabel/ Indikator pertanyaan } & \multicolumn{5}{|l|}{ Skor Masing-Masing Jawaban } \\
Responden & SS & S & CS & TS & STS \\
\hline a. Kecepatan & & & & & \\
\hline
\end{tabular}




\begin{tabular}{|c|c|c|c|c|c|}
\hline \multirow[t]{2}{*}{ Variabel/ Indikator pertanyaan } & \multicolumn{5}{|c|}{$\begin{array}{l}\text { Skor Masing-Masing Jawaban } \\
\text { Responden }\end{array}$} \\
\hline & SS & $\mathrm{S}$ & $\mathrm{CS}$ & $\mathrm{TS}$ & STS \\
\hline $\begin{array}{l}\text { 1. Tidak membutuhkan waktu yang lama } \\
\text { dalam pemrosesan }\end{array}$ & 5 & 19 & 11 & 4 & 1 \\
\hline $\begin{array}{l}\text { 2. Cepat dalam menampilkan informasi } \\
\text { yang dibutuhkan }\end{array}$ & 7 & 19 & 11 & 2 & 1 \\
\hline b. Keakuratan & & & & & \\
\hline 1. Menghasilkan informasi yang jelas. & 17 & 19 & 4 & 0 & 0 \\
\hline $\begin{array}{l}\text { 2. Kemudahan dalam melakukan } \\
\text { pemesanan. }\end{array}$ & 21 & 16 & 3 & 0 & 0 \\
\hline
\end{tabular}

Untuk dapat menjawab ke empat pertanyaan pada Tabel 1, skor ideal adalah skor yang ditetapkan dengan asumsi bahwa setiap responden menjawab ke-empat pertanyaan tersebut. Skor setiap pertanyaan adalah sebagai berikut :

1) Skor Jawaban

Tabel 2. Skor Jawaban Kuisioner Penelitian

\begin{tabular}{|l|l|}
\hline Skala Jawaban & Skor \\
\hline Sangat Setuju & 5 \\
\hline Setuju & 4 \\
\hline Cukup Setuju & 3 \\
\hline Tidak Setuju & 2 \\
\hline Sangat Tidak Setuju & 1 \\
\hline
\end{tabular}

2) Skor Ideal

Skor ideal digunakan untuk menghitung skor untuk menentukan rating scale dan jumlah seluruh jawaban. Untuk menghitung jumlah skor ideal (kriterium) dari seluruh item, digunakan rumus berikut :

Skor Kriterium $=$ Nilai Skala $\mathrm{x}$ Jumlah Responden

Tabel 3. Skor Kriterium Penelitian

\begin{tabular}{|l|l|}
\hline Nilai skala $\times$ Jml. Responden & Skor \\
\hline $5 \times 40=200$ & 5 \\
\hline $4 \times 40=160$ & 4 \\
\hline $3 \times 40=120$ & 3 \\
\hline $2 \times 40=80$ & 2 \\
\hline $1 \times 40=40$ & 1 \\
\hline
\end{tabular}

\section{Dengan ketentuan berdasarkan tabel 4 sebagai berikut :}

Tabel 4 Skala Sikap Penelitian

\begin{tabular}{|l|l|l|}
\hline Nilai Skala x Jml. Responden & Skor & Ket \\
\hline $161-200$ & SB & Sangat Baik \\
\hline $121-160$ & B & Baik \\
\hline $81-120$ & CB & Cukup Baik \\
\hline $41-80$ & TB & Tidak Baik \\
\hline $0-40$ & STB & Sangat Tidak Baik \\
\hline
\end{tabular}

Setelah melakukan pembagian kuesioner maka hasil dari jawaban responden terkait pertanyaanpertanyaan yang diberikan ditunjukkan pada tabel 5 berikut ini: 
Tabel 5. Jumlah Jawaban Responden Terhadap Pertanyaan

\begin{tabular}{|c|c|c|c|c|}
\hline \multirow[t]{2}{*}{ No. Responden } & \multicolumn{4}{|c|}{ Jawaban Responden Terhadap Item Pertanyaan } \\
\hline & 1 & 2 & 3 & 4 \\
\hline 1 & 4 & 5 & 5 & 5 \\
\hline 2 & 5 & 4 & 5 & 4 \\
\hline 3 & 3 & 3 & 4 & 3 \\
\hline 4 & 5 & 5 & 5 & 5 \\
\hline 5 & 4 & 4 & 5 & 5 \\
\hline 6 & 4 & 5 & 5 & 5 \\
\hline 7 & 3 & 3 & 4 & 4 \\
\hline 8 & 1 & 1 & 5 & 5 \\
\hline 9 & 5 & 5 & 5 & 5 \\
\hline 10 & 4 & 5 & 5 & 5 \\
\hline 11 & 5 & 5 & 5 & 4 \\
\hline 12 & 5 & 5 & 5 & 5 \\
\hline 13 & 3 & 4 & 4 & 5 \\
\hline 14 & 4 & 4 & 4 & 5 \\
\hline 15 & 3 & 3 & 4 & 4 \\
\hline 16 & 3 & 4 & 4 & 4 \\
\hline 17 & 4 & 4 & 4 & 5 \\
\hline 18 & 4 & 4 & 5 & 5 \\
\hline 19 & 3 & 3 & 4 & 4 \\
\hline 20 & 4 & 4 & 4 & 4 \\
\hline 21 & 4 & 4 & 4 & 4 \\
\hline 22 & 2 & 3 & 4 & 4 \\
\hline 23 & 2 & 2 & 3 & 3 \\
\hline 24 & 3 & 3 & 4 & 5 \\
\hline 25 & 4 & 4 & 5 & 5 \\
\hline 26 & 3 & 4 & 5 & 5 \\
\hline 27 & 2 & 3 & 3 & 4 \\
\hline 28 & 4 & 4 & 5 & 4 \\
\hline 29 & 3 & 3 & 4 & 5 \\
\hline 30 & 2 & 3 & 3 & 3 \\
\hline 31 & 4 & 4 & 5 & 5 \\
\hline 32 & 4 & 4 & 5 & 5 \\
\hline 33 & 4 & 4 & 4 & 4 \\
\hline 34 & 4 & 4 & 4 & 4 \\
\hline 35 & 3 & 4 & 4 & 4 \\
\hline 36 & 3 & 3 & 4 & 5 \\
\hline 37 & 4 & 4 & 4 & 4 \\
\hline 38 & 4 & 4 & 5 & 4 \\
\hline 39 & 4 & 3 & 3 & 5 \\
\hline 40 & 4 & 3 & 4 & 5 \\
\hline Jumlah & 143 & 150 & 173 & 178 \\
\hline
\end{tabular}

Setelah melakukkan Analisa lebih detail maka hasil perhitungan yang lebih detail ditunjukkan pada gambar 6 berikut ini:

Tabel 6. Tabulase Persentasi(\%) Tanggapan Responden

\begin{tabular}{|c|c|c|c|c|c|c|c|c|c|c|c|c|c|}
\hline \multirow{3}{*}{ No } & \multicolumn{13}{|c|}{ Tanggapan Responden } \\
\hline & \multicolumn{5}{|c|}{$\begin{array}{c}\text { Skor Untuk Masing-Masing } \\
\text { Jawaban }\end{array}$} & \multirow{2}{*}{$\begin{array}{c}\text { Hasil } \\
\text { Skor } \\
\text { Tertinggi }\end{array}$} & \multirow{2}{*}{$\begin{array}{l}\text { Skor } \\
\text { Ideal }\end{array}$} & \multirow{2}{*}{$\begin{array}{c}\text { Jumlah } \\
\text { Respon } \\
\text { den } \\
\end{array}$} & \multicolumn{5}{|c|}{ Persentase Tanggapan Responden } \\
\hline & SS & $\mathrm{S}$ & $\mathrm{CS}$ & $\mathrm{TS}$ & STS & & & & SB & B & CB & TB & STB \\
\hline 1 & 25 & 76 & 33 & 8 & 1 & 143 & 200 & 40 & - & $71.5 \%$ & - & - & - \\
\hline 2 & 35 & 76 & 36 & 2 & 1 & 150 & 200 & 40 & - & $75 \%$ & - & - & - \\
\hline
\end{tabular}




\begin{tabular}{|c|c|c|c|c|c|c|c|c|c|c|c|c|c|c|}
\hline 3 & 85 & 76 & 12 & 0 & 0 & 173 & 200 & 40 & $\begin{array}{c}86.5 \\
\%\end{array}$ & - & - & - & - \\
\hline 4 & 105 & 64 & 9 & 0 & 0 & 178 & 200 & 40 & $89 \%$ & - & - & - & - \\
\hline \multicolumn{8}{|c|}{ Hasil } & 644 & 800 & 40 & \multicolumn{7}{|c|}{-} \\
\hline
\end{tabular}

Dari hasil jawaban pertanyaan, maka menghitung persentase jawabannya yaitu :

1. Persentase : $(143: 200) * 100 \%$ adalah $71.5 \%$ dari $100 \%$ yang diharapkan.

2. Persentase : $(150: 200)^{*} 100 \%$ adalah $75 \%$ dari $100 \%$ yang diharapkan.

3. Persentase : $(173: 200) * 100 \%$ adalah $86.5 \%$ dari $100 \%$ yang diharapkan.

4. Persentase : $(178: 200) * 100 \%$ adalah $89 \%$ dari $100 \%$ yang diharapkan.

Dari Hasil perhitungan akhir dari tabel 6 diperoleh hasil sesuai dengan persamaan 1 di atas maka hasil perhitungan skala likert dalam Penelitian ini adalah sebagai berikut:

$$
644 / 800 \times 100 \%=80.5 \%
$$

Untuk menyimpulkan hasil pengolahan data kuisioner maka terlebih dahulu harus mengetahui nilai interval penilaian yang telah ditetapkan.

Hasil presentase $0 \%-19,99 \%$ : Sangat Tidak Layak

Hasil Presentase 20\% - 39,99\% : Tidak Layak

Hasil Presentase 40\% - 59,99\% : Ragu-ragu

Hasil Presentasi 60\% - 79,99\% : Layak

Hasil Presentasi $80 \%-100 \%$ : Sangat Layak

Berdasarkan hasil persentase penilaian makan Penelitian ini dikategorikan sangat layak untuk diterapkan pada tempat Penelitian.

\section{Kesimpulan}

Berdasarkan hasil Penelitian dan proses pengembangan aplikasi yang Penulis lakukan, maka penulis menyimpulkan beberapa hal sebagai berikut:

a. Pengujian yang dilakukan dengan metode uji Skala Likert dengan hasil $80.5 \%$, total skor tersebut termasuk dalam kategori Sangat Layak.

b. Dari hasil pengukuran yang dilakukan menunjukan bahwa sistem informasi e-menu berbasis web-mobile pada Cafe Raego dapat mempermudah pelanggan dalam melakukan pemesanan makanan dan minuman.

\section{Saran}

Diharapkan bagi peneliti selanjutnya yang ingin mengembangkan sistem informasi sejenis dengan yang peneliti lakukan agar kiranya dapat dikembangkan dengan menambahkan beberapa fitur yang sesuai dengan keadaan ataupun kebutuhan untuk meningkatakan pelayanan. Dalam hal fitur-fitur yang telah ada lebih ditingkatkan lagi baik dalam segi performa maupun stabilitas.

\section{Ucapan Terima Kasih}

Penulis mengucapkan terima kasih kepada STMIK Adhi Guna sebagai tempat bernaung penulis selama ini menjalani karir penulis. Selain itu Penulis juga mengucapkan terima kasih kepada teman, sahabat dan kerabat yang ada di sekitar penulis, tanpa mereka penulis tidak akan 
jadi seperti sekarang ini. Dan Terima kasih juga untuk pembaca artikel ini. Semoga ilmu ini dapat bermanfaat bagi kita semua

\section{Daftar Pustaka}

[1] Anwar, S.P, Alfonsius, E, Nurmansyah., 2017, Permodelan Sistem Informasi Layanan Unit Pengaduan Pelayanan (UP3) Publik Rumah Sakit Umum Anutapura, Seminar Nasional Multi Disiplin Ilmu, e-ISSN = 2598-5191, p-ISSN = 2598-4969, November 2017.

[2] Martono., 2018, Pembuatan Aplikasi E-Menu (Electronic Menu) Berbasis Website Dan Android, JURNAL ILMIAH MEDIA SISFO Vol. 12, No. 1, Hal 1036-1046, April 2018

[3] Roger S.Pressman,Software Engineering. Edisi 7 : Pendekatan Praktisi Tujuh, 2010

[4] Jos, F.T., Steven, R.S., Alicia, A.E.S., 2016, Rancang Bangun Aplikasi Pemesanan Menu Makanan Restoran Berbasis Android, E-journal Teknik Informatika, Vol 9, No 1, October 2016,. 